\title{
Book Review: Tourism in Russia, a management handbook
}

\author{
Yana Wengel
}

University of Waikato, New Zealand

Tourism in Russia - A management handbook edited by Frederic Dimanche and Lidia Andrades is a timely and informative report, by an international group of researchers from $16 \mathrm{EU}$ and Russian institutions, on topical issues concerning tourism in Russia. Authors collaborated to report the results of an EU-funded project aimed to boost the competitiveness and sustainability of tourism as well as enhancing the curricula in higher education institutions in the Russian Federation. Since midtwentieth century, the tourism industry in Russia has been acknowledged as a complex economic sector, and as such has attracted scholarly attention from a range of disciplines including geography, anthropology, politics, sociology and business studies. Tourism in Russia, the world largest country, remains in its infancy.

This volume is designed as a handbook to address two topic areas: tourism management theory and aspects of tourism in Russia. Russia is positioned as a country of controversies, long history, rich resources and business opportunities. The volume balances between essential tourism management theory and a studied analysis of the state of tourism development in the Russian Federation. In this, authors examine the complexities of tourism development in a context of geopolitical pressures and rising economic development. In my opinion, these authors get to the heart of issues they report on by critical reflection about a variety of aspects of the current Russian tourism market. Why is this work of importance? The editors have compiled an academically sound volume on a topic which has attracted little scholarly attention in the past. As such, it will be of interest to a wide range of audience including students, academics, professionals and policy-makers.

Although this handbook is a topically organised book focusing on tourism management in Russia, it is set out like a textbook with case study examples. Thus it could be used for instruction purposes. The book offers a solid foundation for understanding the current Russian tourism sector and the complexities involved in growing the sector by creating linkages between management techniques, theory and current examples. Combined, the three sections provide a situational and Strengths, Weaknesses, Opportunities, and Threats (SWOT) analysis of the Russian tourism sector and offer guidelines of how to strengthen tourism curricula at Russian higher education institutions. Authors adopt a value chain management approach to reveal connections between different stakeholders in the tourism sector and tourism impacts. The first section provides an overview of the current tourism market in Russia, a theoretical background on tourist behaviour and appropriate management techniques. Section two summarises specific and significant tourism markets in Russia: as a cultural tourism destination with rich traditions; as an emerging nature-based tourism destination; as a health and wellness tourism destination; unique elements/characteristics inherited from Soviet times and the MICE (Meetings, Incentives, Conferences, and Exhibitions) sector. Section three concludes by reflecting on global trends and challenges faced the sector while providing an overview of the importance of tourism education in Russia and the direction that it should take.

There are advantages and disadvantages to how the book is structured. It may appear as if it attempts to cover too many topics and the table of content looks somehow confusing having four distinct levels. On the other hand, the book provides current examples and case studies relevant to Russian tourism market, which are useful in linking theory to practice. What is more, the book offers 
clear chapter's introduction and summary with questions for further discussion at the end of each chapter.

The authors acknowledge the difficulty of writing about Russian tourism as a whole, due to its size, development stage and market specialities. They point out that, in recent years, the tourism market is rapidly developing despite the economic and geopolitical challenges. Tourism policy-makers and the government have undertaken many steps to develop sustainable tourism practices in Russia. This was a vital step but is not sufficient yet. The field still has a long way to go to achieve market sustainability. This is the concern outlined through many chapters of the book. As tourism has the potential to create serious advantages in terms of economic benefits, it could also bring negative impacts to the destinations and communities if not managed properly. That is why the need for more qualified staff and changes in Russian tourism studies curricula at the higher education institutions is highlighted. The final section examines the future of tourism describing the trends of the sector and issues particularly relevant for the Russian market.

This is an appealing handbook for a wider audience who aim to understand tourism impacts in Russia at a macro and micro level. As far as I can evaluate, this book provides an honest perspective on the sustainability debate in the Russian tourism and outlines attempts of the government to improve Russian tourism sector. After all, developing the tourism sector in Russia under the proper management might bring countless opportunities for in- and outbound tourism sectors. Altogether, this publication is enjoyable reading which is written in a scientific manner yet comprehensible for a wider audience than academics. 